Portland State University

PDXScholar

\title{
Translanguaging through Story: Empowering Children to Use their Full Language Repertoire
}

\author{
Erin E. Flynn \\ Portland State University, flynn2@pdx.edu \\ Selena L. Hoy \\ Portland State University \\ Jessica L. Lea \\ Portland State University \\ Monica A. Garcia \\ Portland State University
}

Follow this and additional works at: https://pdxscholar.library.pdx.edu/socwork_fac

Part of the Bilingual, Multilingual, and Multicultural Education Commons

Let us know how access to this document benefits you.

\section{Citation Details}

Flynn, E. E., Hoy, S. L., Lea, J. L., \& García, M. A. (2019). Translanguaging through story: Empowering children to use their full language repertoire. Journal of Early Childhood Literacy. https://doi.org/10.1177/ 1468798419838569

This Post-Print is brought to you for free and open access. It has been accepted for inclusion in Social Work Faculty Publications and Presentations by an authorized administrator of PDXScholar. Please contact us if we can make this document more accessible: pdxscholar@pdx.edu. 
running head: TRANSLANGUAGING THROUGH STORY

Translanguaging through story: Empowering children to use their full language repertoire

\author{
Erin Elizabeth Flynn \\ Selena L. Hoy \\ Jessica L. Lea \\ Mónica A. García \\ Portland State University \\ PO Box 751 \\ Mailcode: SSW \\ SSW Portland, OR 97207 \\ flynn2@pdx.edu
}

This is the accepted version of the following article:

Flynn, E. E., Hoy, S. L., Lea, J. L., \& García, M. A. (2019). Translanguaging through story: Empowering children to use their full language repertoire. Journal of Early Childhood Literacy. https://doi.org/10.1177/1468798419838569

which has been published in final form at https://doi.org/10.1177/1468798419838569. This article may be used for non-commercial purposes in accordance with the Sage Green Open Access policy. 


\section{Translanguaging through story: Empowering children to use their full language repertoire}

The U.S. is ever-diversifying. As of 2014, one in six kindergarteners were identified as English Language Learners (NCES, 2017), and one in three preschool children served by the early childhood program Head Start spoke a language other than English as the primary language in the home (Office of Head Start, 2018). Multilingual children have always been an important part of our story in U.S. schools (Mondale \& Patton, 2001), and will likely continue to be a more rather than less common facet of our school landscape (Hornberger \& Link, 2012).

Despite this, multilingual children have often been shortchanged in U.S. classrooms (Cheatham \& Jimenez-Silva, 2011; Hornberger \& Link, 2012; Souto-Manning, 2016). Languages other than English are often considered an obstacle to skillful reading and writing in the U.S.: "Educational practices overwhelmingly favor compartmentalized, monolingual, written, decontextualized language and literacy practices" (Hornberger \& Link, 2012: 245). "Good readers" are often defined in terms of their ability to behave and display knowledge in ways valued by the dominant culture (Souto-Manning, Dernikos, \& Yu, 2016), which overwhelmingly favors monolingual, English displays.

\section{Emerging Multilingualism: An Underutilized Resource in the Early Childhood}

\section{Classroom}

By viewing language as a resource rather than a problem, teachers can engage their students more fully in learning (García, Sylva, \& Witt, 2011; Gort \& Sembiante, 2015; Orellana \& García, 2014; Palmer, Martínez, Mateus, \& Henderson, 2014). As Palmer, Martínez, Mateus, and Henderson, write, "more and more educators are beginning to 
consider the capacity to communicate in languages other than English as an asset to be developed in school: an academic advantage that can lead to bilingualism, biculturalism, and biliteracy" (2014, p. 757).

Indeed, by embracing multilingualism, we allow children to draw from their entire linguistic repertoire, instead of just a small part of it. A child's linguistic repertoire includes their personal language resources which result from their cumulative experiences using language with others (Otheguy, García, \& Reid, 2015). The theory of translanguaging advocates for the gains made possible by supporting children in using and developing their full language repertoires.

Translanguaging is the way that multilingual children interpret, process, and communicate, flexibly using linguistic resources to make meaning with others (Orellana \& García, 2014). Research in preschool classrooms shows that children are strategic, responsive to context, and sensitive to the requirements of communicative partners when playing in the classroom (Bengochea, Sembiante, \& Gort, 2017). In fact, children translanguage all the time between, for example, academic and home language, or formal and informal language. The ease with which children do so demonstrates great intuition and sophistication (Orellana \& García, 2014).

\section{The Role of Teachers in Supporting Translanguaging}

Teachers play an important role in supporting multilingual children. For example, $86 \%$ of Head Start programs serve children who speak a language other than English as the primary language in the home (McNamara, 2016). And yet, only 30\% of Head Start child care staff are proficient in a language other than English (Office of Head Start, 2018), suggesting a need to recruit and retain bilingual teachers in early childhood education. 
Monolingual teachers or teachers who speak other languages than their students can still support translanguaging. Lucas and Katz (1994) show that monolingual teachers have a number of strategies they can use to support their students. Strategies identified include: allowing students who speak the same language to pair up to help each other or ask questions; encouraging support from family members; reading books in the students' home language. In a study conducted by Taylor, Bernhard, Garg, \& Cummins, (2008), teachers partnered with kindergarten parents to create dual-language books in both English and home languages, which were then shared in the classroom.

\section{Storytelling as a Vehicle for Activating Children's Full Linguistic Repertoire}

Creating opportunities for children to use their full language repertoire is vitally important for supporting multilingual children's language development, because it provides practice in using more than one language and emphasizes the value of multilingualism as a way of being in the world (Sayer, 2012; Souto-Manning, 2016). Weekly, child-led storytelling offers a valuable way for children to practice using language and to learn from one another (Flynn, 2016). Story circles, a small group storytelling activity, consist of small groups of children who take turns telling a story of their own choosing. The same children meet from week to week, exchanging stories which range from personal accounts to imaginative stories. When provided the opportunity to participate in story circles, children's storytelling supports language learning as well as serving social functions such as building connections to other children or making important points (Flynn, 2016).

The true value in providing the space for storytelling and language practice is shown in the variety that can come from a single classroom (Flynn, 2018a). Story styles are 
no doubt impacted by culture (Cheatham \& Jimenez-Silva, 2011; McCabe, 1997; Michaels, 1981), as seen historically in the variations between folklore in different regions of the globe (Stadler \& Ward, 2005). The use of multiple languages in one classroom and one story circle provides a unique opportunity for improving language socialization in the classroom as children build confidence by learning from one another.

\section{Present Study}

This paper reports on the storytelling of one child who was a participant in a larger, year long study of storytelling in three multilingual preschool classrooms serving lower socioeconomic status (SES) children of diverse language backgrounds. The larger study investigated how multilingual children used their full language repertoires to tell stories in a small group storytelling activity with a particular focus on describing how children's storytelling changed over time.

This paper investigates the storytelling of Diego (pseudonyms are used for all participants in the study), an emerging bilingual, whose home language was Spanish. Diego was teacher identified as a child who needed additional support with language in both his home language and English. Diego was selected as the focal child for this paper in order to illustrate how children in need of additional support with language participate in an activity that invites and encourages using language in extended turns. Diego was also selected because the participating teachers in the study engaged with Diego, directly seeking to encourage, extend, and better understand Diego's storytelling in a way that was not needed for children with greater facility with language. Examining Diego's storytelling and the way that teachers engaged with him offers insight for monolingual and bilingual 
teachers seeking to support language development in young, emerging bilingual children. Thus, this study asks:

How does a young, emerging bilingual use his full linguistic repertoire to tell stories in a small group storytelling activity?

How does his language use change over time?

How do teachers support storytelling in the context of a small group storytelling activity?

\section{Method}

\section{Description of the Study}

Multilingual classrooms. The study took place in three urban, culturally and linguistically diverse Head Start classrooms in the Pacific Northwest of the U.S. Head Start is an early childhood program within the U.S. which supports school readiness by nurturing early learning, health, and family well-being for lower SES families (Office of Head Start, 2018).

Story circles. Each of the three participating classrooms implemented, what was for them a new activity, called story circles. Story circles are a child-led storytelling activity in which small groups of children meet once a week to tell a story of their own choosing. The teacher acts as a facilitator who listens and helps the children take turns. The same group of children meets each week over the course of the school year, exchanging stories.

Rooted in the radical, civil rights work of the Student Nonviolent Coordinating Committee (SNCC), story circles can be used for diverse purposes, but always place an emphasis on finding common cause and inclusion (O’Neil, O’Neil, Hofmann, \& Rao, 2006). Story circles are thought to be a culturally responsive teaching practice in that they do not just draw on Black activism and cultural forms (Michna, 2009; 0’Neil, O’Neil, Hofmann, \& 
Rao, 2006; Randels, 2005), but on Indigenous talking circles, a traditional way of bringing First Nations peoples together for "listening, teaching, sharing, and learning" (MacLean \& Wason-Ellam, 2006, p. 31).

In early childhood education, story circles have been shown to surface a range of story genres (Flynn, 2018a) and culturally-shaped meaning making patterns when children tell stories in culturally and linguistically diverse classrooms (Flynn, 2018b). Though story circles hold the potential to bring about greater social cohesion in the classroom, young children have also been shown to use storytelling as a tool to exert power and give primacy to some ways of making meaning over others (Flynn, 2018b).

\section{Participants}

Classroom children. The focal classroom consisted of a diverse group of fourteen children, many of whom were in their second year in the classroom together. The children ranged in age from four years and one month to five years and one month $(M=4.6, S D=.37)$. The majority of the children in the classroom were boys, who made up $64 \%$ of the classroom. Considerable linguistic diversity existed in the classroom with $28.6 \%$ of the children speaking English as the primary language in the home, 28.6\% Spanish, 21.4\% Arabic, 7.1\% Somali, 7.1\% Creole, and 7.1\% Russian, per parent report.

Focal child. The focal child for this study was Diego. Diego was 4 years and 7 months old at the beginning of the study. He was parent identified as Latino and as speaking Spanish primarily in the home. At the beginning of the school year, Diego's receptive and expressive vocabulary in English measured almost two standard deviations below average (See Table 1.). The teachers in the classroom considered Diego a child who 
needed additional support with language in both English and Spanish based on classroom observation and assessment.

[INSERT TABLE 1]

Teachers. The teachers in the focal classroom consisted of a lead teacher, Teacher Loretta, who was an European American, monolingual English-speaking teacher and an assistant teacher, Teacher Sofia, who was a bilingual Latina. Teacher Loretta and Teacher Sofia were assisted by the classroom aide, Teacher Madison, a monolingual Englishspeaker. All three of the teachers took turns running the story circles with children.

Teacher Loretta established strong routines in the classroom aimed at helping children with minimal experience with English catch on to the rhythm of classroom life and more fully participate in classroom activities. She used gesture, simplified her speech, and utilized pictorial representations to communicate with children and establish shared understanding. Children readily repeated routine phrases that were used to guide classroom life like the daily reminder when lining up to go outside that, "Friends go first."

Teacher Sofia supported children in times when they needed further guidance. Her use of phrases in Spanish that were familiar to Diego and his classmates helped them transition seamlessly while their confidence in their skills and independence continued to grow along with their classmates. She injected Spanish into the daily routines with repeated phrases like the reminder to "limpie sus pies (wipe your feet)" which greeted children as they returned from playing outside. Sofia modeled translanguaging throughout the school day and was responsive to the needs of children to flexibly use multiple languages as well, encouraging participation over insisting on English proficiency. 
Researchers. The research team consisted of a lead investigator of European American origin who identifies as a monolingual English speaker, but has elementary speaking and reading ability in Spanish. The lead investigator was assisted by two practicing social workers, pursuing their Master's Degree in Social Work at the time of the study. One was a European American who had basic proficiency in Spanish. The other identified as a bicultural, bilingual Japanese-American who speaks Japanese and English. The research team was assisted by a bilingual, Latina colleague with a Master's degree in Education who reviewed the story circle transcripts, offering input on translation.

\section{Data Collection}

Story circles. Children participated in story circles once a week from October to May. They told stories in the story circle a total of 25 times. In the first couple weeks of the study, an adult began the circle by modelling a short story of personal experience. In subsequent weeks, the story circle began with children taking a turn as the first to tell a story. Teacher example stories were no longer provided. Story circles are an activity structure which elevates and amplifies the voices of children. Teacher talk is typically minimized in story circles as a primary goal of the activity is for children to listen, share, and learn from one another.

In the focal classroom a total of 237 stories were told over the course of the school year. Each child told on average $16.93(\mathrm{SD}=4.89)$ stories over the course of the year with a range of 10 to 24 stories told per child. Diego told fewer stories than average; 14 in all. When not telling a story, Diego was an attentive listener for others.

In the first month of the activity, the story circles took an average of three minutes and 24 seconds $(S D=1.67)$ per story group with each child taking an approximately 40 
second turn. In the last month of the activity, the story circle groups lasted an average of 12 minutes and 29 seconds $(\mathrm{SD}=4.22)$ with children taking turns that took just under 3 minutes to complete. Diego's first story took approximately 25 seconds. His last story continued for just under three minutes.

All story circles were audio recorded and transcribed. Each transcription was double checked by a second member of the research team to ensure accuracy. Discrepancies were settled through discussion. Transcripts that included translanguaging by teachers or children were reviewed a third time, in the case of Diego's stories, by a Spanish dominant speaker.

Classroom observation. Classroom observations were carried out two times per week, once on the day of story circles as well as one other day of the week. Classroom visits typically lasted from 2.5 to 3 hours, beginning with the morning breakfast and concluding as children readied for lunch. In total, 40 classroom observations were completed for the focal classroom. In 21 of the observations, the focal child, Diego, was shadowed for at least a portion of the classroom day. Artifacts of children's drawing, writing, and art were documented through photography.

The researchers collected observations using a participant observer approach with the researchers assuming a "quasi-friend" role, striking a balance between developing rapport with children and seeking to minimally alter the classroom day (Purcell-Gates, 2004). As much as possible, researchers sat back as observers, aiming to be as unobtrusive to the "ordinary life of the classroom" (Purcell-Gates, 2004, p. 102). In our role as observers, children frequently sought to draw us into play, engage us in mealtime 
conversations, and welcome us as members of the classroom, which Teacher Loretta and Teacher Sofia encouraged.

Our day began as the children's started, sitting with the classroom during breakfast and then joining them in their morning circle. Without the responsibility of holding the children accountable, our role became somewhat of a neutral advocate. This gave us the opportunity to be engaged in different games with the children, to continue to build relationships, and to see first-hand the interactions between friends. Our approach to understanding how the children communicated with others both supported the study and our ability to build unique relationships with each child.

\section{Data Analysis}

For the larger study, stories were analyzed using a systemic functional linguistics approach (SFL) (Halliday \& Matthiessen, 2004) in which stories were first parsed into clause level ideas, which unfold through configurations of participants, processes, and circumstances. Story stages were determined based the functional purpose and grammatical realization of clause level ideas. Stories genres unfold through a series of story stages as genres are staged, goal-oriented uses of language (Martin \& Rose, 2008). Each genre is realized through a defining story stage which occurs in the middle of a story. Narrative stories are defined by the presence of a complicating event. Recount stories are realized through a series of events. Observational stories are realized through description and an evaluative comment (See Flynn, 2018a for more thorough description of the coding process). For example, Teacher Loretta modeled telling an observation type story in interaction with Diego. 
Teacher Loretta's story began with a story stage called an Abstract. The functional purpose of an abstract is to make a meta-statement about what a story is about, readying the listener for what is to become. This functional purpose can be realized in a number of different ways, but often unfolds through saying processes, being processes, and circumstances of matter.

\begin{tabular}{|l|l|l|l|l|}
\hline I & can tell & you & a story & about sharks. \\
\hline Sayer & Saying Process & Receiver & Verbiage & Circumstance of Matter \\
\hline
\end{tabular}

Loretta followed the Abstract with an Orientation, which has the functional purpose of situating events in an experiential context, often grammatically realized through circumstances of time, location, and clause complex constructions.

The next stage of Teacher Loretta's story is Description. Though she used a doing process to characterize how the sharks "were swimming," rather than a being process more commonly found in description, she described the general conditions in which she "saw sharks one time."

She concluded her observation with an Evaluative Comment which fulfills the functional purpose of providing an interpersonal take on events. Evaluative Comments help the listener understand the significance of what has been relayed and unfold through sensing and saying processes through which one communicates what they think and feel.

I can tell you a story about sharks.

I saw sharks one time. When I went to the aquarium.

And they were swimming above my head. In a tank. And I could look up.

And I felt like I could touch them.
Abstract

Orientation

Description

Evaluative Comment 
In the present study, Diego's stories were analyzed for interactional and thematic patterns. Interactional patterns included an analysis of who Diego interacted with and how during the story circle activity. Storytelling interactions were coded for whether Diego interacted with a child, teacher, or both. Interactions were also coded in terms of the nature of the interaction - story invitation, continuation, expansion, clarity, closure, or appraisal. [INSERT TABLE 2]

Thematic patterns traced the use of ideational threads (Flynn, 2018b) - participants, processes, and circumstances - in Diego's stories. Ideational threads were documented in Diego's storytelling from week to week as well as across participation frameworks in the classroom day. For instance, an example of an ideational thread would be the participant sharks in Teacher Loretta's story. Every time, sharks were named in the story circle, children's art, play, or conversation, the ideational thread of sharks was continued. Documenting the repetition of an idea shows how ideas were continued by children and teachers, over time, and in different activity frameworks.

\section{Results}

Diego was selected as the focal child for this paper, because though his experience was unique, he represented several important larger patterns in the study. Below, we briefly describe two larger patterns as well as one distinct aspect of Diego's story circle participation. Then, we examine the larger patterns in relationship to the progression of Diego's storytelling across the course of the school year.

The children's storytelling reflected known features of storytelling including language patterns present in distinct genres of story. A main finding of the larger study was that even children in need of additional support with language deployed language in ways 
reminiscent of more mature storytellers, demonstrating the basic foundations of distinct storytelling genres like narratives, recounts, and observations.

Repetition, variation, and expansion of important ideas acted as a vehicle for language learning. A main finding of the larger study was that children continued ideational threads - participants, processes, and circumstances - from story to story and across activity frameworks during the classroom day. The continuation of ideational threads occurred in a couple ways that are evident in Diego's storytelling. First, children frequently repeated favorite stories, varying and improving their telling over time. Second, children of all language abilities continued ideas across activity settings in the classroom, such that a story told in the story circle would frequently become the subject of play during free play or outdoor recess. Children also continued ideas from their stories in their drawings and classroom talk during daily meals. In this way, children nurtured important ideas across the course of the school year.

Diego's participation in the storytelling activity was distinct in that the teachers directly engaged with Diego during the story circle, inviting and encouraging extended talk. The majority of children directly engaged with other children by responding to each other's ideas and commenting back and forth on each other's storytelling. Only 15\% of Diego's storytelling turns showed evidence of direct interaction with other children.

Teachers mainly invited and briefly appraised children's storytelling, purposely limiting teacher-child interaction so that children could more directly shape the activity. However, the majority of Diego's interactions were teacher initiated and teacher directed as Diego used the story circle time to tell about story participants that mattered to him. He 
actively listened when other children told their stories, but required more encouragement to tell his own story.

\section{Diego's Storytelling}

In the classroom, Diego often engaged in quiet play, infrequently using language. Instead, he relied on other resources like gesture and animated facial expressions to convey his intentions. Diego often chose to stay in at recess and help the Spanish speaking assistant teacher, Teacher Sofia, set up the lunch tables. The two would maintain a running back and forth in Spanish, which seemed to offer some respite for Diego as much of the classroom instruction and play unfolded in English. In the beginning of the year, Diego's most frequent playmate was a slightly younger, Spanish speaking boy in the neighboring classroom. The two would run and play on the playground, engaged in chase games as they pretended to be sharks, monsters, and Power Rangers.

Across the course of the school year, Diego told a total of 14 stories in the story circle. In the analysis below, we present six representative examples of Diego's storytelling as well as one story dictation Diego completed for a classroom drawing. The story beginning, timing, language use, and story genre is presented below.

[INSERT TABLE 3]

\section{First Attempts at Storytelling}

Diego's first story was short, but signaled an important beginning for making sense of experience through story as he told a structurally complete recount type story in Spanish. Diego began his first story circle tentatively as did many of the children in the classroom who seemed initially uncertain about what it meant to tell a story in this new classroom activity. When it was his turn, Diego turned to Teacher Sofia, the assistant 
teacher in the classroom, asking, “¿En Español? (In Spanish?)” Teacher Sofia nodded and responded by modeling translanguaging as she drew on the resources of Spanish and English, “¿Cómo dice tu story? (How does your story go?)” He paused and considered, encouraged by his teacher, "Yo escucho. (I'm listening.)" As the circle of children stood up to leave, he continued:

Un tiburón nadaba en el agua. (A shark swam in the water.)

Y comía personas (eating sounds). (And ate people.)

Y nadaban en agua y comían y comían. (And they swam in the water and ate and ate.) Y ya. (That's it.) ${ }^{1}$

In this first story turn, Diego began by orienting his listeners in terms of the participant of interest, un tiburón (a shark), and location, en el agua (in the water).

\begin{tabular}{|l|l|l|}
\hline Un tiburón & nadaba & en el agua. \\
\hline Actor & Doing Process & Circumstance of Location \\
\hline
\end{tabular}

Orientations that introduce the time, location, and participants of interest are an important part of relaying experiences to an audience and a key feature of storytelling. He followed this orientation with an event, punctuated by sounds that mimicked eating. Then, he shifted to say they swam in the water and ate and ate, perhaps making an overarching, summary statement about sharks in general. In this summary statement, Diego employed repetition, a common rhetorical device used to provide emphasis and reinforce a story's meaning. In this case, something shocking like a person being eaten by a shark was portrayed by Diego as common for sharks. Diego concluded his story as many of the children did with a short statement of conclusion like, "That's it," or "Y ya." In this first storytelling attempt, Diego

\footnotetext{
${ }^{1}$ Stories have been transcribed verbatim, including errors in article-noun agreement, verb conjugation, and unknown or unclear words. Small errors of this type are common in the sample for children speaking in Spanish and in English. As a result, at times the intended meaning of an utterance is unclear.
} 
told a short, but complete recount type story, consisting of an Orientation, a series of Events, and a Statement of Conclusion.

In the weeks that followed, Diego told short, single event stories. A few days before Halloween, Diego was prompted to tell a story by Teacher Sofia. She said, “¿Diego, listo? (Diego, ready?)" Another teacher commented, “Okay, your turn.” Diego asked, "To share? In Spanish?" He then said,

\section{Una vez. (One time.) \\ I go as un shark.}

The English-speaking teacher commented, “Más? (More?)” Diego continued, “Pero (but)” before going quiet and indicating he was finished.

This story is shorter than Diego's first story which he told in his home language of Spanish. In this story turn, Diego used both English and Spanish, drawing on the language available to him to relay an experience of relevance to him. Diego continued his idea about sharks, introduced in his first story about "un tiburón (a shark)." His story also drew on his play in the classroom. For instance, Diego played chase games on the playground in which he and a friend pretended to be sharks. His story was also possibly inspired by the arrival of Halloween and the flurry of talk it inspired in the classroom around dressing up and taking on alternative roles.

Two weeks later, Diego continued with the idea of a shark. This time, with teacher Sofia absent, Diego was interacting with English speaking teachers. The teacher prompted Diego, saying, “Diga un cuento (Tell a story.)” To which Diego responded, "I tell an, a story in English." He continued:

One day is a shark.

Um. 
The teacher queried, "What did the shark do?" Diego shouted enthusiastically, "Swimming!" After this interjection, Diego fell quiet and when prompted indicated that he was done with his turn.

Known features of story. In these early stories, Diego moved flexibly between English and Spanish using both languages within a single story as well as trying out telling a story in each language. Though his story contributions in these first weeks were short and at times felt incomplete, Diego demonstrated some foundational understanding of story. For instance, he oriented his listener in each story turn by situating events in time as well as introducing the participant of interest. Each story contained at least one event. His most complete storytelling turn was his first, when he told a recount type story in his home language of Spanish. It is this first storytelling turn, in the language he preferred, that most clearly indicates that Diego knows and can reproduce the patterned way that language unfolds when storying experience.

Repetition, variation, and expansion of ideas. The continuation of ideational threads was evident in Diego's early stories, which in the first two months centered on a shark or un tiburón as the participant of interest. These early stories raise ideas that Diego continued to play with over the course of the school year such as the idea that sharks eat people and the idea of being a shark. Diego continued these ideational threads in his outdoor play, playing shark chase games during outdoor recess, animating his stories in play.

Interactional support. In these early stories, the teachers' primary interactional strategy was to invite Diego's storytelling without seeking to encourage continuation or expansion of the story with the exception of when Diego was asked, "What did the shark 
do?" The strategy of inviting and listening was the primary strategy practiced by teachers in the study as story circles as an activity setting rely on children using language, listening to language, and engaging in storytelling repeatedly over time as the lever to bring about more complete and complex storytelling. While other children in study began to readily tell stories by the second month of the activity, Diego had told only four stories; all but one consisted of a single event.

\section{Telling Stories Together}

As a result, several of Diego's stories in the middle of the year took on a conversational quality as the teacher leading the circle and Diego engaged in an extended back and forth aimed at helping him to make a story contribution that went beyond a single event. From December to March, Diego told six stories, four of which unfolded as more conversational turns in which teachers engaged in multiple bids to invite storytelling, as well as encourage the continuation of the story and expansion of participants, processes, and circumstances in the story.

For instance, one day the lead teacher in the classroom, Teacher Loretta, led the story circle. A monolingual English speaker, Loretta heard that Diego had told a story about sharks the previous two weeks. He was reluctant to tell a story this week and Loretta commented, “Do you want to do it again. ¿Por favor? (Please?)” The two continued:

Teacher Loretta: Tell me! I don't know about the shark. And I love sharks. Diego: You tell me. Teacher Loretta: I want to hear your story. Diego: You tell me.

Teacher Loretta: I can tell you a story about sharks.

I saw sharks one time.

When I went to the aquarium.

And they were swimming above my head. 
In a tank.

And I could look up.

And I felt like I could touch them.

Diego: That shark swimming in the water!

Teacher Loretta: They do. And then what?

Diego: They eat. They eat. The. Fish.

(Diego paused, looking uncertain about what to say)

Teacher Loretta: You can tell me in Spanish. ¿Habla Español? (Do you speak Spanish?)

Diego: They can eat fish!

Teacher Loretta: They can eat fish. Cause they. What kind of teeth do they have?

Diego: No.

Teacher Loretta: No. Do they have sharp teeth?

Diego: No, like this. (Points to his teeth.)

Teacher Loretta: Ooh. Those are good teeth for eating fish. And then what? What happened after that? When I ...

Diego: Nothing.

Teacher Loretta: Nothing?

When I saw the fish swimming.

There was a big. Little ones like this.

And then all of a sudden.

Diego: No, no, no.

Teacher Loretta: There was a big one.

Diego: The shark. Is a big shark.

Teacher Loretta: Woah! How big?

Diego: Like this. (Holds arms wide.)

Teacher Loretta: Woah! Sounds kind of scary. Were you scared?

Diego: Hmm. I'm all done.

Teacher Loretta: You're all. Alright.

Diego: And the shark. (Diego looks at a piece of paper that a child dropped near his feet.)

And. Was. Eated, a paper.

Was like paper.

And eat fish. Milk. Breakfast.

I'm done.

In this extended story turn, Diego was reluctant to tell a story, but Teacher Loretta used several techniques to provide support for Diego and encourage him to make a contribution. First, Loretta encouraged Diego, expressing interest in sharks and using 
Spanish and English to invite his storytelling. When Diego insisted that Loretta tell him about sharks, Teacher Loretta modeled a simple observational story in which she provided several known features of story. This was the only time in the study that a teacher model of this kind was provided beyond the first weeks of the study.

She modeled a story beginning a second time, providing a story stem when she said, "When I saw the fish swimming. There was a big. Little ones like this. And then all of a sudden ..." Teacher Loretta then used questions to encourage Diego to continue the story, saying things like: "And then what," "How big," "Were you scared?" At a moment when Diego fell silent and seemed stuck, Teacher Loretta encouraged, "You can tell me in Spanish. ¿Habla Español? (Do you speak Spanish?)”

The end result of Loretta's attempts to scaffold Diego's storytelling was far more language use than Diego had previously used in the circle. He used gesture to show the size of the shark and to call attention to his pointy teeth. In the end, Diego drew on what was in the context of his own classroom to finish the story, naming things that the shark ate like a piece of paper near Diego's feet, fish, and milk and breakfast which Diego, himself, had just finished before the story circle. Throughout the interaction, Diego continued a similar pattern to his first story circle turns in that he was excited and animated when he was talking, but reluctant and uncertain in the moments in between when he needed to determine what to say and how to say it.

In the months that followed, Diego alternated between declining his turn to tell a story while listening patiently to other children and telling short multi-event stories about shared interests in the classroom such as playing in the snow. Then, in March he was encouraged to tell a story by Teacher Sofia in another back and forth exchange that had a 
conversational quality. Teacher Sofia began with a story invitation, saying, "Cuentame una historia. ¿Qué es lo que quiere contar? Tu tienes buenas historias. (Tell me a story. What do you want to say? You have good stories.) Ready?" After a few attempts to get Diego started, Teacher Sofia asked Diego about what he watches on television, a favorite conversational topic of Diego's. The two continued:

Teacher Sofia: ¿Qué ves en la televisión? (What do you see on the television?) Diego: Power Rangers.

Teacher Sofia: Cuentame de Power Rangers. (Tell me about the Power Rangers.)

Diego: Mm-mm. Porque salen monstruos. (Because the monsters come out.)

... the back and forth exchange continues.

Diego: ... Que se transforma. (... that changes into.)

Teacher Sofia: ¿Y qué se transforman? (And what do they become?)

Diego: Y. Y. Y su.

Y sus megaforce. (And their megaforce.)

De Jayden. (With Jayden.)

El Power Ranger Rojos. (The red Power Ranger.)

Que se convierte en robot. (That becomes a robot.)

Y. Atacaran a los monstruos. (And. They attacked the monsters.)

Teacher Sofia: ¿Y quién ganó? ¿Quién ganó? (And who won? Who won?)

Diego: Antonio.

Habían monstruos. Más monstruos. (There are monsters. More monsters.)

Y después se cayeron los árboles. (And after the trees fell.)

Y después no lo creo yo. (And after I couldn't believe it.)

Porque es un Power Rangers Dorado. (Because it is a gold Power Ranger.)

Teacher Sofia: Oh! OK.

Diego: Me, cuento más. (I tell more.)

Y después. Los Power Rangers de Jayden ganaron. (And after. Jayden's Power

Rangers won.)

Y vi una vicatura ${ }^{2}$ de otro. Power Ranger Samurai. (And I saw a victory of the other.)

Power Ranger Samurai.)

Y después. Um. Um. (And after.)

Dieron un volcán y que había. Un dinosaurio Rex. (They gave a volcano and there

2 The intended meaning may be la victoria which means victory in Spanish. 
was. A dinosaur Rex.)

Y era. Um. De calor. No era de verdad. (And it was. Um. Hot. It wasn't really.)

Y después. Um. Um. (And after ...)

El monstruo de hielo lo congela. (The ice monster freezes it.)

Y después. Los otros monstruos se convirtieron en dragon. (And after. The other monsters become a dragon.)

Y después. El T-Rex um pelea contra los dos dinosaurios malos. (And after. The T-

Rex fights against the two bad dinosaurs.)

Teacher Sofia: Wow. ¿Y quién ganó? (Wow. And who won?)

Diego: Um. Jayden.

Teacher Sofia: Oh. OK.

Diego: Y después. Era muy salvaje. (And after. It was wild.)

The end.

Diego's conversational story turn was a leap forward in storytelling. One that Diego would continue to build on in the final months of the school year.

Known features of story. During these conversational story turns Diego deployed language in ways consonant with recount and narrative type stories. Diego made a considerable advance in storytelling: 1) telling about a series of events; 2) introducing complicating events typical of narrative type stories; 3) evaluating events with interpersonal commentary like "no lo creo yo (I couldn't believe it) and "Era muy salvaje (It was wild);" and 4) using more advanced vocabulary like transformar (transform), convertir (convert), and atacar (to attack).

Repetition, variation, and expansion of ideas. In these conversational turns, Diego continued ideational threads from previous stories and from classroom play, drawing on familiar participants of interest to populate his stories. For instance, later in the day while manipulating clay during free play, Diego orchestrated a pretend Power Rangers' battle while commenting to one of the researchers, "The monster it was, it was, I told you. It was scary. And then the Power Ranger Antonio fight and fight. All the way to the monster. 
And then the monster was destroyed." In this way, stories were repeated, practiced, and varied across classroom contexts and across languages, depending on the interactional partner.

Interactional support. The conversational story turns differed from previous story turns and from stories told by children in the larger sample, because Teacher Loretta and Teacher Sofia engaged Diego not just before and after Diego's storytelling turn, but in the middle of the turn. The stories Diego told during the middle of the year were characterized by extended story invitations in which both teachers sought to help Diego initiate a story based on known interests from previous story circles and classroom play. Teacher Sofia's engagement illustrates the most common pattern of interaction practiced during this part of the year with Diego as she used questions to encouraged expansion by asking Diego to tell more about the participants, processes, and circumstances of his story.

\section{Telling a Story on His Own}

Nearly six months after telling his first story in the story circle, Diego had progressed significantly in his storytelling ability. Though he told stories about many different things over the course of the year, in many respects, it was the stories that he returned to, telling them in English and Spanish, and on multiple occasions, which seemed to provide a special opportunity for language growth. His final four stories reflected and extended several of his early and ongoing ideational threads.

A favorite story of Diego's built on his earlier conversational story about the Power Rangers and the monsters. When it was his turn, Diego said:

Once upon a time. It's faster on the Power Rangers. 
Once upon a time.

The Power Rangers.

Was.

Fight.

And the Power Rangers.

Antes (before) hurt the monsters.

And then the. The monsters.

Was destroying.

The people.

And then.

The Power Rangers.

And the monsters, the Power Rangers.

Was.

Strong.

And then the Power Rangers fight.

And the monster fight.

And then the Power Rangers.

In, and the gold. Power Ranger.

Was fast.

And then.

The Power Ranger Gold.

Fight with the monsters.

And the Power Ranger Gold.

Not move.

And the Gold Power Ranger destroy the monster.

Sin (without).

Without.

And he not move.

And the Power Ranger Red was stuffing at the Power Ranger Gold.

And Damon (a student from class) was there.

And then.

The monsters.

Was.

Went to destroy the Power Rangers.

And the monster won the energy.

And, the Power Ranger won the energy.

Really big. 
And the Power Rangers.

And then.

The Power Rangers fight.

The end.

Known features of story. In this story, Diego held the floor and told a multi-event story which included several known conventions of story. For instance, he began the story with "Once upon a time," and concluded with "The end." Diego included complicating or problematic events which are common to narrative type stories like when "the monsters. Was destroying. The people," or, when "the monster won the energy." Knowledge of story conventions plays an important role in preparing children to be successful readers and writers, because children can better anticipate, recognize, and reproduce the valued patterns through which language unfolds in written texts.

Repetition, variation, and expansion of ideas. As in previous story turns, Diego returned to important participants of interest and ideas. The gold Power Ranger and the red Power Ranger featured as the two Power Rangers of interest as did monsters as the villains to be defeated. The action unfolded as the participants, "fight," "destroy," and "win." The importance of being "fast," reemerged in this story as well, which was an idea that Diego raised in his conversational turn with Sofia earlier in the year.

Interactional support. In the final months of the story circle activity the interactional pattern between Diego and the teachers returned to the patterned practiced at the beginning of the year. The teachers invited Diego to tell a story, listened, and briefly appraised the story with a neutral or positive comment. This pattern of story invitation and brief appraisal was the most common interactional support provided for children. As the year progressed, Diego no longer needed additional encouragement to tell a story that 
went beyond a single event. As he did throughout the year, Diego made sensitive choices about language, telling stories in Spanish and English depending on the language preference of the adult leading the circle.

\section{Stories Outside the Story Circle}

Diego practiced the valued patterns of language present in stories in his play and drawings as storytelling permeated the children's classroom life. With Teacher Loretta's encouragement, the children in the classroom began telling stories to go along with their daily drawings. By the end of the year, Diego's stories and drawings demonstrate several known conventions of story. For instance, Diego drew a picture of a beetle family when the class was studying insects.

[Insert Image 1]

Diego began his beetle story with a prototypical orientation which set the scene in terms of time, location, and participants of interest.

\begin{tabular}{|l|l|l|l|}
\hline One day & the beetles & go & to the park. \\
\hline Circumstance of Time & Actor & Doing Process & Circumstance of Location \\
\hline
\end{tabular}

Then, Diego announced the presence of a problem, a defining feature of narrative stories (Bruner, 1983). Diego clearly knew this common convention of story and was able to reproduce it in his own stories. Conventionally, stories relay not just what happened, but how to think and feel about what has occurred (Bruner, 1983). Storytellers achieve this through evaluation of the events. Moments like when Diego said, "It was terrible," evaluate what happened in the story, helping the listener understand the interpersonal importance of events. 
In this drawing and story, Diego continued many of the ideas he had been working on in his story circle stories, including a monster and a Power Ranger. He inserted a popular classmate that he occasionally played chase games with into the action as he had in his previous story, giving the story instant cachet by stating, "And then Damon was there." Damon was a student who lead chase games that included monsters, dinosaurs, and various ferocious animals all year at recess. For boys in the classroom like Diego, Damon was the center of the action. It would be a shared understanding of the children that if Damon was there, something heroic was about to ensue.

Diego also continued ideas from his stories in the context of his play. For instance, months after his conversational storytelling turn with Teacher Loretta, Diego was playing on the playground, pretending to be a "shark monster," a pretend role he assumed on more than one occasion. He turned to a nearby researcher who had had small conversations with Diego in Spanish to explain, "I see a shark movie. A shark man and lava boy." He continued explaining that sharks have "a sharp teeth." He then began speaking in Spanish, telling how sharks bite people. He made a pretend biting motion in the air and gave a serious look to convey the significance of the revelation. The researcher nodded in response and Diego continued his shark monster play.

Diego also took up the ideas of other children to build on and advance his interests in new directions. For instance, one morning, Diego was playing in the pretend boat structure on the playground with Jason, a child in his story circle group who frequently told stories about heroes wielding lasers to save the day. The two continued in a back and forth as other children in the class joined in the game:

Diego: Sharks! 
Jason: I'll get them with a undersea laser! Sit down, it's gonna get creepy.

Diego: There are sharks against the boat.

Jason: Hand me my laser, will ya.

Diego: Your feet! The laser! (He handed an imaginary laser to a researcher)

Sadiq: (Walks by the boat) But sharks when they bite people they will say, "Yuck."

(Diego runs up and gives the researcher a fist bump)

Damon: (Comes into the boat) I can drive.

Diego: You want to go to Fish World?

Nadim: I'm back here!

Diego: A shark is coming! It broke the laser!

Diego: We're here at a house. Stay here. With the broke laser.

Émelina: I drive. Shark is coming!

(Diego stands in the prow and shoots sharks with his laser)

It can be easy to overlook the significance of everyday playground scenes like this one. However, an examination of Diego's stories, drawings, and play show the way that children like Diego can find multiple and reinforcing ways to communicate the ideas that are relevant to them. Further, one can see how story conventions like complications become solidified for children like Diego. Problems were introduced in play and the children worked together to "fight" and "win" - important ideas in Diego's stories that reflect a larger language pattern of narrative stories in which complications, problems, or obstacles are introduced and ultimately resolved. Diego practiced this pattern in his stories as well as in his drawings and play.

Diego began the year as a somewhat shy child who often chose to stay in at recess so that he could help Teacher Sofia set the table and spend time talking together in Spanish. As the year progressed, Diego became more comfortable using language to explain his thoughts and feelings, to tell about the block houses he built and the games he played. Just as other children in the classroom had done, Diego tried out new ideas and stories in Spanish first, only later retelling or telling a similar story in English. This shows what a 
powerful resource Spanish remained for Diego in making sense of and communicating his ideas in the classroom.

\section{Discussion}

This study set out to understand how an emerging bilingual used his linguistic repertoire to tell stories in a small group storytelling activity called story circles. And, how the way he used language changed over time. Examination of Diego's participation in story circles shows how storytelling holds untapped potential for multilingual children to more fully use their language repertoire.

A brief glimpse into the storytelling trajectory of Diego shows a young child languaging in many ways. From intimate lunch table conversations in Spanish to exuberantly rallying the group to fight sharks to using gesture, English, and Spanish to communicate to a multilingual group of children and teachers, Diego's language development consists of much more than learning to effectively use English. The learning that Diego is undertaking is how to make sensitive, sophisticated, intuitive shifts in language based on social and situational demands. When teachers recognize this kind of language sophistication as a valued learning end, they can much more readily support children to more fully use their language repertoire.

Ideational threads run like cords through Diego's school year as he repeated, varied, and expanded on ideas of interest to him. Engaging with the same ideas, in multiple modalities, multiple times, over a long period of time offered a particularly supportive context for language learning as Diego was able to draw on his full linguistic repertoire to deepen his understanding and improve his capacity to construe experience over the course of the school year. 
Perhaps, most important, Diego was able to get support for telling stories in English and Spanish, with the assistant teacher, Teacher Sofia, filling a crucial role encouraging the use of Spanish. Teachers like Sofia model what it looks like to be bilingual in an academic space, while monolingual teachers like Loretta show that even teachers who are not bilingual themselves can value and encourage children to use their full language repertoire in the service of completing academic tasks like telling a story. Tellingly, though nearly a third of the children in the classroom spoke Arabic as their primary language in the home, only one child told a story in Arabic, suggesting the critical importance of bilingual teachers who can model bilingualism and engage with children using their home language.

\section{Conclusion}

It would be easy for early childhood teachers to conclude that being routinely invited to tell a story in front of a small group of children is too challenging a task for a child like Diego, who in the beginning of the year used language sparingly, and needed support for communicating ideas in both his home language and English. However, even this reluctant storyteller who began the year with single event stories blossomed, developing the confidence to tell more. Providing the time, space, and a teacher who spoke his language gave Diego the opportunity to keep refining his ideas and his ability to effectively communicate them in story, a form highly valued in schooling, yet intimately connected to the rhythm of drawing and play. 


\section{Appendix}

Table 1.

Fall Receptive and Expressive Vocabulary Measured in English.

\begin{tabular}{c|c|c|c|c}
\hline Assessment & Diego & Overall Class & & \\
\hline & & Mean & (SD) & Range \\
$\begin{array}{c}\text { Receptive Vocabulary (PPVT- } \\
\text { 4) }\end{array}$ & 61 & 94.92 & 23.88 & $61-143$ \\
$\begin{array}{c}\text { Expressive Vocabulary (EVT-2) } \\
\text { ( }\end{array}$ & 64 & 89.67 & 18.59 & $55-125$ \\
\hline
\end{tabular}

Note: The PPVT-4 and EVT-2 are norm referenced vocabulary assessments with a Norm average of 100 and Standard Deviation of 15.

Table 2.

Storytelling interactional moves.

\begin{tabular}{|c|c|c|}
\hline $\begin{array}{l}\text { Interactional } \\
\text { Move }\end{array}$ & Description & Example \\
\hline Invitation & $\begin{array}{l}\text { Request or encouragement to tell } \\
\text { a story }\end{array}$ & $\begin{array}{l}\text { Cómo dice tu story? (How does your } \\
\text { story go?) }\end{array}$ \\
\hline Continuation & $\begin{array}{l}\text { Request or encouragement to } \\
\text { continue a story }\end{array}$ & They do. And then what? \\
\hline Expansion & $\begin{array}{l}\text { Request or encouragement to tell } \\
\text { more about a participant, process, } \\
\text { or circumstance in a story }\end{array}$ & $\begin{array}{l}\text { Que más sale ahí? (What else was } \\
\text { there?) }\end{array}$ \\
\hline Clarity & Request for clarification of a story & What did you say? \\
\hline Closure & $\begin{array}{l}\text { Request or encouragement to end } \\
\text { a story }\end{array}$ & $\begin{array}{l}\text { Think of a good way to end your } \\
\text { story. }\end{array}$ \\
\hline Appraisal & $\begin{array}{l}\text { Comment on the characteristics or } \\
\text { quality of a story }\end{array}$ & That was a good story. \\
\hline
\end{tabular}


Table 3.

Representative Examples of Diego's Storytelling in Order Presented.

\begin{tabular}{l|l|l|l}
\hline \multicolumn{1}{c|}{ Story } & Month Told & Language Used & Story Genre \\
\hline Un tiburón nadaba ... & October & Spanish & Recount \\
Una vez. I go ... & October & Spanish \& English & Single Event \\
One day is a shark ... & November & English & Single Event \\
That shark swimming ... & December & English & Recount \\
Power Rangers ... & March & Spanish & Narrative \\
It's faster on the Power Rangers ... & April & English \& Spanish & Narrative \\
One day the beetles ... & May & English & Narrative \\
\hline
\end{tabular}




\section{Image 1.}

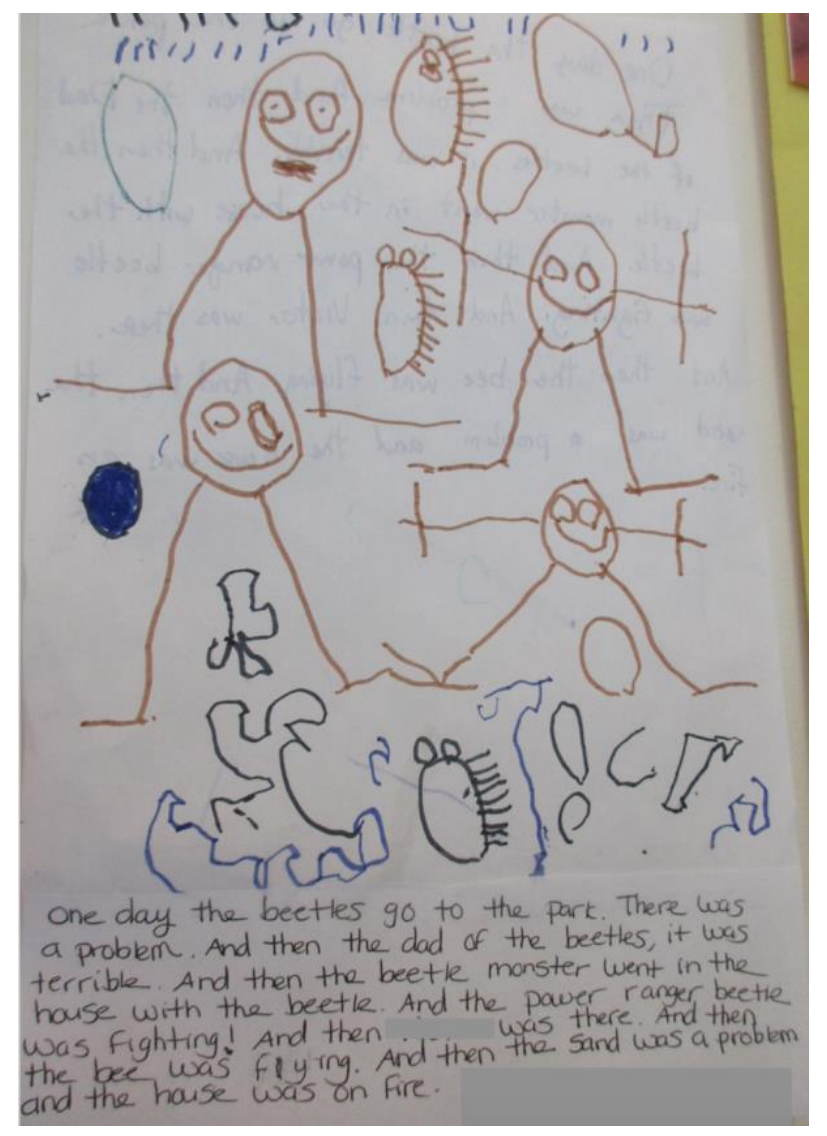

One day the beetles go to the park.

There was a problem.

And the dad of the beetles, it was terrible.

And then the beetle monster went in the house with the beetle.

And the Power Ranger beetle was fighting! And then Damon was there.

And then the bee was flying.

And then the sand was a problem and the house was on fire. 


\section{References}

Bengochea, A., Sembiante, S. F., \& Gort, M. (2017). An emergent bilingual child's multimodal choices in sociodramatic play. Journal of Early Childhood Literacy, 0(0), 1-33. DOI: $10.1177 / 1468798417739081$

Bruner, J. S. (1983). In search of mind: Essays in autobiography: New York: Harper \& Row. Cheatham, G and Jimenez-Silva, M. (2011). What makes a good story? Supporting oral narratives of young children from culturally and linguistically diverse backgrounds. Childhood Education, 87(4), 261-268, DOI: 10.1080/00094056.2011.10523188

Flynn, E. E. (2016). Language-rich early childhood classroom: Simple but powerful beginnings. The Reading Teacher, 70(2), 159-166. https://doi.org/10.1002/trtr.1487

Flynn, E. E. (2018a). Storying experience: Young children's early use of story genres. Text and Talk, 38(4), 457-480. https://doi.org/10.1515/text-2018-0010

Flynn, E. E. (2018b). Ideas in dialogue: Leveraging the power of child-led storytelling in the multicultural preschool classroom. Language in Society, 47(4), 601-633. https://doi.org/10.1017/S0047404518000593

García, O., Sylvan, C., \& Witt, D. (2011). Pedagogies and practices in multilingual classrooms: Singularities in pluralities. The Modern Language Journal, 95(3), 385400. Retrieved from http://www.jstor.org.proxy.lib.pdx.edu/stable/41262374

Gort, M. and Sembiante, S.F. (2015). Navigating Hybridized Language Learning Spaces Through Translanguaging Pedagogy: Dual Language Preschool Teachers' Languaging Practices in Support of Emergent Bilingual Children's Performance of 
Academic Discourse, International Multilingual Research Journal, 9:1, 7-25, DOI: $10.1080 / 19313152.2014 .981775$

Halliday, M.A.K., \& Matthiessen, C.M.I.M. (2004). Introducing functional grammar. New York: Edward Arnold.

Hornberger, N. H., \& Link, H. (2012). Translanguaging in today's classrooms: A biliteracy lens. Theory Into Practice, 51(4), 239-247. doi:10.1080/00405841.2012.726051

Lucas, T., \& Katz, A. (1994). Reframing the Debate: The Roles of Native Languages in English-Only Programs for Language Minority Students. TESOL Quarterly, 28(3), 537-561.

MacLean, M., \& Wason-Ellam, L. (2006). When Aboriginal and Métis teachers use storytelling as an instructional practice. Retrieved from https://documents.sd61.bc.ca/ANED/educationalResources/Storytelling/Storytelli ng_As_An_Instructional_Practice.pdf.

Martin, J. R., \& Rose, D. (2008). Genre relations: Mapping culture. Equinox.

McCabe, Allyssa (1997). Cultural background and storytelling: A review and implications for schooling. The Elementary School Journal 97(5):453-473.

McNamara, K. (2016). Dual language learners in Head Start: The promises and pitfalls of new reforms. Migration Policy Institute. Retrieved from https://www.migrationpolicy.org/article/dual-language-learners-head-startpromises-and-pitfalls-new-reforms

Michaels, S. (1981). “Sharing time”: Children's narrative styles and differential access to literacy. Language in Society, 10(3), 423-442. 
Michna, C. (2009). Stories at the center: Story circles, educational organizing, and fate of neighborhood public schools in New Orleans. American Quarterly, 61(3), 529-555.

Mondale, S., \& Patton, S. B. (Eds.). (2001). School: The story of American public education. Beacon Press.

National Center for Educational Statistics (NCES). (2017). The condition of education. Retrieved from https://nces.ed.gov/pubs2017/2017144.pdf.

Office of Head Start. (2018). Head Start program facts: Fiscal year 2017. Retrieved from https://eclkc.ohs.acf.hhs.gov/about-us/article/head-start-program-facts-fiscalyear-2017.

O’Neil, B., O’Neil, J., Hofmann, A., Rao, S. (2006). Storytelling in the name of justice. Retrieved from http://www.racialequitytools.org/resourcefiles/nyuwagner.pdf.

Orellana, M. F., \& Garcia, O. (2014). Language brokering and translanguaging in school. Language Arts, 91(5), 386-392. Retrieved from http://www.ncte.org/journals/la/podcasts

Otheguy, R., García, O., \& Reid, W. (2015). Clarifying translanguaging and deconstructing named languages: A perspective from linguistics. Applied Linguistics Review, 6(3), 281-307.

Palmer, D. K., Martínez, R. A., Mateus, S. G., \& Henderson, K. (2014). Reframing the Debate on Language Separation: Toward a Vision for Translanguaging Pedagogies in the Dual Language Classroom. The Modern Language Journal, 98(3), 757-772. doi:10.1111/j.1540-4781.2014.12121.x

Purcell-Gates, V. (2004). Ethnographic research. In N. K. Duke \& M. H. Mallette (Eds.), Literacy research methodologies, (92-113). New York: Guilford Press. 
Randels, J. (2005). After the storm: The story circle. Education Week. Retrieved from https://blogs.edweek.org/teachers/randels/

Sayer, P. (2012). Translanguaging, TexMex, and bilingual pedagogy: Emergent bilinguals learning through the vernacular. TESOL Quarterly, 47(1), 63-88. doi:10.1002/tesq.53

Souto-Manning, M. (2016). Honoring and Building on the Rich Literacy Practices of Young Bilingual and Multilingual Learners. The Reading Teacher, 70(3), 263-271. doi:10.1002/trtr.1518

Souto-Manning, M., Dernikos, B., \& Yu, H. M. (2016). Rethinking normative literacy practices, behaviors, and interactions: Learning from young immigrant boys. Journal of Early Childhood Research, 14(2), 163-180. doi:10.1177/1476718x14548782

Souto-Manning, M., \& Rabadi-Raol, A. (2018). (Re)Centering Quality in Early Childhood Education: Toward Intersectional Justice for Minoritized Children. Review of Research in Education, 42(1), 203-225.

Stadler, M., \& Ward, A. (2005). Supporting the Narrative Development of Young Children. Early Childhood Education Journal, 33(2), 73-80.

Taylor, L. K., Bernhard, J. K., Garg, S., \& Cummins, J. (2008). Affirming plural belonging: Building on students' family-based cultural and linguistic capital through multiliteracies pedagogy. Journal of Early Childhood Literacy, 8(3), 269-294. doi.org/ $\underline{10.1177 / 1468798408096481}$ 